\title{
PEMBINAAN KELOMPOK PEMELIHARA AZOLLA MICROPHYLLA DI DESA SUNGAI KAYU ARA, SIAK
}

\author{
Irwan Effendi*1, Afrizal Tanjung ${ }^{2}$, Syahril Nedi ${ }^{3}$, Syafruddin Nasution $^{4}$ dan Elizal $^{5}$ \\ 1,2,3,4,5Fakultas Perikanan dan Ilmu Kelautan, Universitas Riau, Pekanbaru. \\ *E-mail: helpingirwan@gmail.com
}

\begin{abstract}
Sungai Kayu Ara Village, Siak Regency, Riau Province is a coastal village. The main livelihoods of the people in this village are farming, fishermen and breeders. Pellets and concentrate feed have been used by the community as fish and livestock feed. But the high price of this feed makes this business less profitable. Azolla microphylla as fish feed and livestock has been introduced in Indonesia. This community service activity aims to train coastal communities of A. microphylla cultivation techniques which will later be used as fish feed and other livestock. This activity was carried out with the following stages; 1) Location survey, group formation and coordination. 2) Get off to the field and prepare sites for training. 3) Training of growing substrate fermentation techniques A. microphylla. 3) Training to prepare A. microphylla growing containers. 4) Cultivation training of A. microphylla. 5) Harvesting and giving A. microphylla to livestock. 6) Monitoring and evaluating the results of the trainings. A group of cultivators of A. microphylla has been formed and training has also been carried out with the students of the 2018 UNRI LPPM KKN participants in this village. This group named "SUKARELA" stands for the Sungai Kayu Ara Pemelihara Azolla with 30 members. Initial monitoring results in the second, third and fourth weeks after training showed that these macrophytes can grow well. Some members have enlarged the maintenance container in the form of maintenance tanks.
\end{abstract}

Keywords-Azolla Microphylla, Fish Feed, Livestock Feed, Cultivation, Community Services, Sungai Kayu Ara.

\begin{abstract}
Abstrak
Desa Sungai Kayu Ara, Kabupaten Siak, Provinsi Riau merupakan desa pesisir. Mata pencaharian utama masyarakat di desa ini adalah bertani, nelayan dan peternak. Pellet dan pakan konsentrat telah digunakan masyarakat sebagai pakan ikan dan ternak. Namun mahalnya harga pakan ini membuat usaha ini kurang menguntungkan. Azolla microphylla sebagai pakan ikan dan ternak sudah mulai dikenalkan di Indonesia. Kegiatan pengabdian kepada masyarakat ini bertujuan untuk melatih masyarakat pesisir tehnik budidaya A. microphylla yang nantinya dijadikan sebagai pakan ikan dan ternak lainnya. Kegiatan ini dilaksanakan dengan tahapan sebagai berikut; 1) Survei lokasi, pembentukan kelompok dan kordinasi. 2) Turun ke lapangan dan persiapan lokasi bagi pelatihan. 3) Pelatihan tehnik fermentasi substrat tumbuh A. microphylla. 3) Pelatihan penyiapan wadah tumbuh A. microphylla. 4) Pelatihan tehnik pemeliharaan A. microphylla. 5) Pemanenan dan pemberian A. microphylla kepada ternak. 6) Monitoring dan evaluasi hasil kegiatan. Kelompok pembudidaya A. microphylla sudah terbentuk dan pelatihan telah pula dilaksanakan bersama para mahsiswa peserta KKN LPPM UNRI 2018 di desa ini. Kelompok ini bernama "SUKARELA" singkatan dari Sungai Kayu Ara Pemelihara Azolla beranggotakan 30 orang. Hasil monitoring awal pada minggu kedua, ketiga dan ke empat pasca pelatihan memperlihatkan bahwa makrofit ini dapat tumbuh baik. Beberapa anggota telah memperbesar wadah pemeliharaan berupa bak-bak pemeliharaan.
\end{abstract}

Kata kunci-Azolla Microphylla, Pakan Ikan, Pakan Ternak, Budidaya,Pengabdian Kepada Masyarakat, Sungai Kayu Ara.

\section{PENDAHULUAN}

Pesisir adalah wilayah peralihan antara ekosistem darat dan laut yang saling berinteraksi. Ekosiaistem ini merupakan daerah pertemuan antara darat dan laut; ke arah darat meliputi bagian 
daratan, baik kering maupun terendam air, yang masih dipengaruhi sifat-sifat laut seperti pasang surut, angin laut, dan perembesan air asin; sedangkan ke arah laut meliputi bagian laut yang masih dipengaruhi oleh proses-proses alami yang terjadi di darat seperti sedimentasi dan aliran air tawar, maupun yang disebabkan oleh kegiatan manusia di darat seperti penggundulan hutan dan pencemaran. Perairan payau merupakan salah satu bagian dari wilayah pesisir. Yaitu suatu zona peralihan air tawar dengan air laut dengan salinitas $0,5-30 \mathrm{ppm}$, dimana organisme yang tumbuh didominasi oleh vegetasi hutan bakau atau mangrove.

Wilayah pesisir, di mana air payau terdapat, merupakan wilayah yang banyak dihuni oleh masyarakat. Di Indonesia, sampai saat ini wilayah ini umumnya masih tergolong daerah tertinggal dimana tingkat kehidupan masyarakatnya masih relatif rendah dibandingkan dengan wilayah daratan (Purnama, 2015 dan Gumilar, 2012). Sumber mata pencaharian masyarakat di wilayah ini adalah perikanan, pertanian, perkebunan, peternakan dan kehutanan (Satria 2015). Di sisi lain potensi sumberdaya alam pendukung sektor-sektor ini telah tereksplotasi maksimal bahkan melebihi potensi yang ada. Lahan-lahan di wilayah pesisir umumnya relatif gersang, dimana senyawa yang mengandung unsur nitrogen merupakan limiting faktor (faktor pembatas).

Penyediaan sumber pakan bagi ternak masyarakat pesisir (ikan, sapi, kambing, bebek, itik dan lain sebagainya) berupa protein hijau (green protein) merupakan salah satu alternatif pemecahan masalah. Penggunaan pakan yang dihasilkan oleh pabrik berupa pelet dan konsentrat di satu sisi telah terbukti memberikan hasil pertumbuhan ikan dan ternak yang baik. Akan tetapi di sisi lain, harga pakan pabrikan yang tinggi, lokasi yang lahan yang jauh, daya beli konsumen lokal terbatas, transportasi tidak lancar dan keterbatasan modal yang dimiliki oleh para petani dan peternak (Hidayat, 2012) membuat usaha ini tidak menguntungkan. Dengan kata lain pakan ini bukan merupakan solusi terbaik bagi mereka.

Makrofilik Azolla microphylla merupakan tumbuhan paku air dengan ukuran yang relative kecil (Christenhusz, 2014), memiliki panjang 1,5-2,5 cm. Tumbuhan ini tumbuh di daerah tropis dan subtropis (Tjitrosoepomo, 2014). Beberapa genus dapat tumbuh di perairan payau, namun biota ini lebih disebut sebagai tumbuhan air tawar. Tipe akar yang dimiliki yaitu akar lateral dimana bentuk akar adalah runcing atau tajam terlihat seperti rambut atau bulu di atas air. Bentuk daun kecil dengan ukuran panjang sekitar 1-2 mm dengan posisi daun yang saling menindih. Para ahli taksonomi menggolongkan Azolla mengelompokkan biota ini ke dalam 7-9 spesies. Mereka adalah Azolla caroliniana Willd, A. circinata Oltz \& Hall, A. cristata Kaulf, A. filiculoides Lam, A. imbricata Nakai, A. japonica Franch. \& Sav, A. Mexicana, A. microphylla Kaulf, A. nilotica A. pinnata dan A. rubra R.Br (Christenhusz, 2014).

Pemanfaatan Azolla sebagai pakan ikan dan ternak lainnya sudah mulai dikenalkan di tanah air . Di Pulau Jawa beberapa situs internet telah mengenal dan memperjualbelikan komoditas ini secara online bagi kebutuhan tersebut (Madigan et al, 2009). Beberapa keunggulan Azolla sebagai paka antara lain adalah sebagai berikut. 1) Kadar protein yang tinggi (23-30 \% berat kering; Kusumanto, 2014). 2) Pertumbuhan yang sangat cepat (3-7 hari; Smith et al, 2010). 3) Relatif mudah dibudidayakan (Chapman, 2010). dan 4) Mudah dicerna dan dibagikan kepada ikan dan hewan ternak.

Ketersediaan unsur hara berupa senyawa nitrogen merupakan permasalahan klasik bagi lahan dan perairan di wilayah pesisir. Tanah umumnya berpasir, sedikit berlempung dan asam dan miskin akan zat hara. Pendekatan permasalahan kekurangan senyawa nirogen (nitrat) di dalam ekosistem air payau tersebut dapat dilakukan dengan perbaikan kualitas air dengan bantuan pengikatan nitrogen bebas dari udara oleh simbion makrofit, cyanobateria dan bakteri di ekosistem tersebut. Untuk itu perlu dicari pendekatan-pendekatan yang tepat memamfaatkan potensi yang ada bagi kesejahteraan masyarakat wilayah pesisir.

Azolla merupakan salah satu jenis tanaman ganggang yang dapat digunakan sebagai pupuk organic sehingga mampu memenuhi kebutuhan hara terutama $\mathrm{N}$ bagi tanaman. Kemampuan menyediakan $\mathrm{N}$ bagi tanaman adalah karena pada Azolla terdapat Cyanobacteria yang kemudian kedunya melakukan simbiosis mutualisme. Simbiosis keduanya kemudian di namakan Anabaena azollae. Simbion ini dapat memfiksasi N2 bebas diudara sehingga dapat meyumbang kebutuhan N bagi tanaman didalam tanah (Sudjana, 2014).

Fiksasi nitrogen adalah proses pengikatan gas nitrogen (N2) dari udara ke dalam air atau tanah oleh tanaman tingkat tinggi bekerjasama (simbiose) dengan organisme tinggkat rendah. 
Selanjutnya gas nitrogen ini akan berikatan dengan molekul air membentuk ion ammonium. Nitrifikasi adalah proses pembentukan senyawa nitrat dari nitrit yang sebelum berasal dari oksidasi senyawa ammonium. Proses ini merupakan proses di mana ion ammonium (NH3) dioksidasi menjadi ion nitrit, seterusnya (NO2 -) menjadi ion nitrat (NO3-); Kroneck et al 2014). Proses ini dapat terjadi di tanah, air laut, maupun air tawar. Meleibatkan bakteri. Bakteri nitrifikasi Nitrosomonas dan Nitrosococcus dan Nitrobacter.Kelompok bakteri ini bersifat kemolitotrof karena menggunakan senyawa nitrogen inorganik sebagai dalam siklus hidupnya. Mikroba ini tidaklah bekerja sendirian, melainkan juga bersiombiose dengan tumbuhan dan hewan lainnya di mana mereka berada.

Di tanah air pemeliharaan Azolla pada saat ini masih dalam kalangan amat terbatas. Tehnik pemeliharaan yang diterapkan masih konvensional dan skala rumah tangga dan memnuhi kebutuhan sendiri. Biota ini hanya ditebar di kolom-kolom air tergenang di tanah (kolam, bak dan lain sebagainya). Kondisi menyebabkan pertumbuhannya tidak maksimal sehingga manfaat yang diberikanpun tentu tidak maksimal pula.

Penyediaan sumber pakan ikan dan ternak masyarakat pesisir (sapi, kambing, bebek, itik dan lain sebagainya) berupa protein hijau (green protein) merupakan salah satu alternatif pemecahan masalah ekonomi masyarakat pesisir. Makrofit Azolla microphylla bersama simbionnya Anabaena azollae dan bakteri nitrifikasi dapat merupakan agen yang bisa diharapkan menjawab kedua permasalahan tersebut. Untuk itu penulis merasa perlu diteliti poptensi pertumbuhan, tehnik budidaya yang tepat (efektif dan ekonomis) dan kemampuan fiksasi nitrogen makrofit ini simbionnya di ekosistem air payau.

\subsection{Perumusan Masalah}

Pengembangan ekonomi masyarakat di wilayah pesisir umumnya melalui usaha pertanian, perkebunan, peternakan, kehutanan dan perikanan. Sektor-sektor pendukung perkembangan ekonomi tersebut sejauh ini belum dapat mengangkat taraf hidup masyarakat setempat. Ironisnya di sisi lain potensi sumberdaya alam pendukung sektor-sektor ini telah tereksplotasi maksimal bahkan melebihi potensi yang ada. Untuk itu perlu dicari pendekatan-pendekatan yang tepat memamfaatkan potensi yang ada bagi kesejahteraan masyarakat wilayah pesisir ini. Penyediaan sumber pakan bagi ternak masyarakat pesisir (ikan, sapi, kambing, bebek, itik dan lain sebagainya) berupa protein hijau (green protein) merupakan salah satu alternatif pemecahan masalah. Ketersediaan unsur hara berupa senyawa nitrogen merupakan merupakan permasalahan klasik bagi lahan dan perairan di wilayah pesisir. Makrofit Azolla microphylla bersama simbionnya Anabaena azollae dan bakteri nitrifikasi merupakan agen yang bisa diharapkan menjawab kedua permasalahan tersebut. Berbagai upaya telah diujicobakan dengan wadah air tawar. Pada hal air tawar terkadang merupakan sesuatu yang sulit diperoleh di daerah pesisir. Untuk itu penulis merasa perlu diteliti potensi pertumbuhan, tehnik budidaya yang tepat (efektif dan ekonomis) dan kemampuan fiksasi nitrogen makrofit ini simbionnya di ekosistem air payau.

\section{METODE}

\subsection{Lokasi dan Waktu Pengabdian}

Kegiatan pengabdian ini akan dilaksanakan di Desa Sungai Kayu Ara, Kecamatan Sungai Apit, Kabupaten Siak, Provinsi riau. Adapun waktunya dilaksanakan bulan Juli-Desember 2018.

\subsection{Tehnik Penyampaian Tujuan dan Manfaat Kegiatan}

Tujuan dan mafaat kegiatan dijelaskan kepada semua peserta oleh Ketua dan Anggota Tim. Program ini melibatkan para mahasiswa peserta Kuliah Kerja Nyata LPPM Universitas Riau (Gambar 1). Materi pelatihan disampaikan dalam bentuk ceramah pemutaran video, tanya jawab, peragaan dan praktek langsung. Diawali dari penyampaian perkenalan anggota tim pengabdian kepada masyarakat LPPM Universitas Riau di Desa Sungai Kayu Ara tahun 2018. Kemudian dilanjutkan dengan pemutaran video pemanfaatan A. microphylla bagi ternak ikan nila, ikan mas, ayam kampung, ayam pedaging, kambing, itik, bebek dan sapi. 


\subsection{Tehnik Fermentasi Substrat Tumbuh A. microphylla}

Kegiatan penyuluhan budidaya A. microphylla oleh masyarakat pesisir dimulai dari kegiatan fermentasi substrat atau sumber energi bagi organisme yang dipelihara. Para peserta mula-mula diberi penjelasan tentang tujuan dan manfaat kegiatan. Kemudian tahap demi tahap diajari bagaimana cara melakukan fermentasi substrat. Materi pelatihan yang diberikan meliputi; peralatan yang dibutuhkan (ember, baskom dan timbangan), bahan fermemtasi (kotoran sapi, tanah dan rumput-rumputan) dan teknik fermentasi (penimbangan bahan-bahan, fermentasi dan pemanenan dan pengontrolan).

\subsection{Tehnik Penyiapan Wadah Tumbuh A. microphylla}

Tahapan berikutnya dalah penyiapan wadah budiadaya. Para peserta diberi penjelasan tahap demi langkah yang mau dilalui dalam penyiapan wadah. Materi yang akan disajikan berupa; penakaran (air dan bahan hasil fermentasi), dan penemapatan wadah (teduh tapi masih mendapatkan sinar matahari di pagi hari).

\subsection{Tehnik Penumbuhan dan Pemeliharaan A. microphylla}

Para peserta diajari bagaimana merawat tanaman sampai panen. Wadah yang sudah siap selanjutnya ditebari bibit $A$. microphylla (jumlah bibit menutupi sekitar $5 \%$ permukaan wadah). Wadah seterusnya ditaruh pada lokasi yang aman. Apabila air wadah berkurang dikarenakan penguapan dilakukan penambahan secukupnya .

\subsection{Tehnik Pemanenan dan Pemberian Kepada Ikan dan Ternak}

Bila semuanya berjalan lancar, maka A. microphylla sudah bisa dipanen Pada hari ke 15 pasca penanaman. Para peserta pelatihan ditnjuki bagaimana cara memanen dan memberikannya atau menyajikannya kepada ikan atau hewan ternak lainnya. A. microphylla yang sudah menutupi seluruh permukaan wadah sudah dapat dipanen secara bertahap sesuai keadaan dan kebutuhan. Caranya cukup menggunakan tangguk atau bahkan dengan tangan sendiri. Sampai pada tahap ini tumbuhan paku ini siap untuk diberikan kepada hewan ternak.

\section{HASIL DAN PEMBAHASAN}

Pembentukan kelompok telah berhasil dilaksanakan. Kelompoknya bernama "SUKARELA" singkatan dari Sungai Kayu Ara Pemelihara Azolla beranggotakan 30 orang (Gambar 2). Dari hasil pengamatan di lapangan terlihat bahwa par anggota kelompok yang didominasi oleh ibu-ibu rumah tangga sangat bersemangat dan atusias mengikuti pelatihan. Semangat tersebut didorong oleh rasa ingin tahun mereka akan hal-hal yang baru dan belum pernh mereka lihat di daerahnya. Selain itu, menurut hasil diskusi di lapangan, ketertarikan ini juga dilatar belakangi oleh nilai ekonomis dari komoditas dan keterampilan yang diberikan. Mereka tertarik akan kemungkinan kemudahan mendapatkan pakan ternak yang lebih murah harganya. Hal ini dapat dipahami karena memang minat dan motivasi petani akan sesuatu komoditas selalu terkait dengan kebaruan dan nilai ekonomis komoditas tersebut (Kurniawan dan Prihtantti, 2018). Priyanto (2016) menyebutkan bahwa aspek keuntungan usaha atau profit merupakan hal amat utama dalam pembinaan para peternak.

Penyuluhan teknis budidaya A. microphylla) ini sudah selesai dilaksanakan. Kegiatan penyuluhan ini berjalan lancar, tertib dan aman. Para peserta mengikuti dengan semangat dan keseriusan yang tinggi terhadap semua materi yang disajikan. Hal ini terlihat ketika adanya beberapa pertanyaan yang diajukan dari peserta kepada narasumber yang mana merupakan bentuk apresiasi dari masyarakat terhadap kegitan yang dilaksanakan. Tim penyuluh juga memberikan penjelasan yang terkait dari pertanyaan dari peserta (Gambar 3, 4, 5, 6 dan 7). Diskusi dan tanya jawab ini bahkan masih berlanjut pada saat tahapan-tahapn praktek pelatihan dilaksanakan. Beberapa peserta justeru baru berani bertanya pada saat berhadapa face to face dengan para instruktur. Sikap seperti ini oleh tim pengabdian dapat dipahami mengingat kebiasaan dan budaya masyarakat Melayu di Desa Sungai Kayu Ara.

Kelompok pembudidaya "SUKARELA" atau Sungai Kayu Ara Pemelihara Azolla diketuai oleh Ibu Neliyati dan sekretaris Ibu Rupawan dengan anggota sebanyak 30 orang (Gambar 6). Para 
anggota berasal dari beberapa Rukun Warga yang ada di Desa Sungai Kayu Ara, Kecamatan Sungai Apit, Kabupaten Siak. Hasil monitoring awal pada minggu kedua, ketiga dan ke empat pasca pelatihan memperlihatkan bahwa makrofit ini dapat tumbuh baik (Gambar 7). Beberapa anggota telah memperbesar wadah pemeliharaan berupa bak-bak pemeliharaan (Gambar 8).

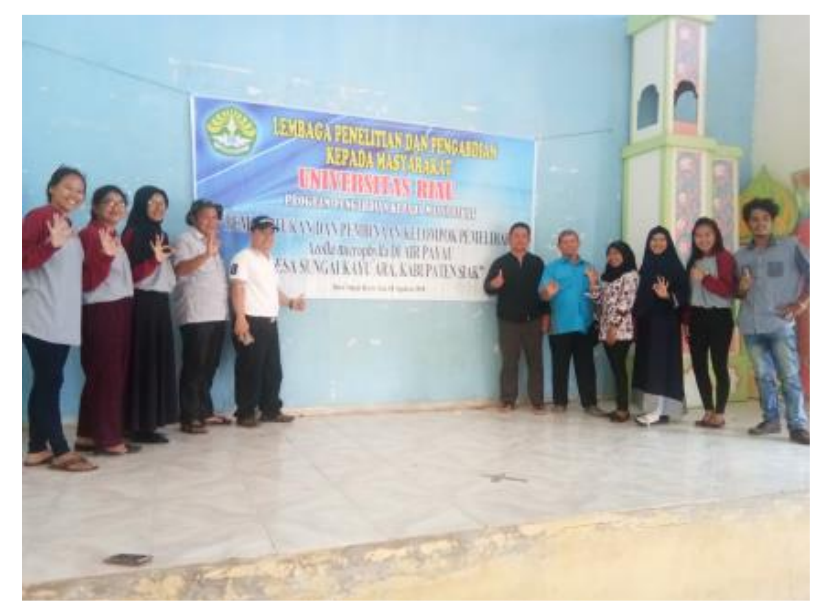

Gambar 1. Tim pelaksana kegiatan bersama mahasiswa/i peserta Kuliah Kerja Nyata LPPM Universitas Riau Tahun 2018 di Desa Sungai Kayu Ara.

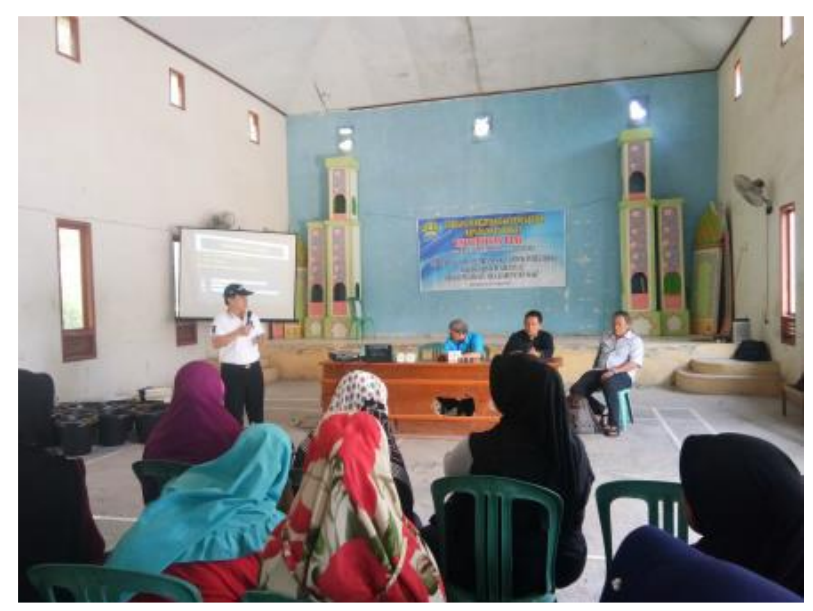

Gambar 2. Ketua Tim menyampaikan materi tehnik budidaya A. microphylla.

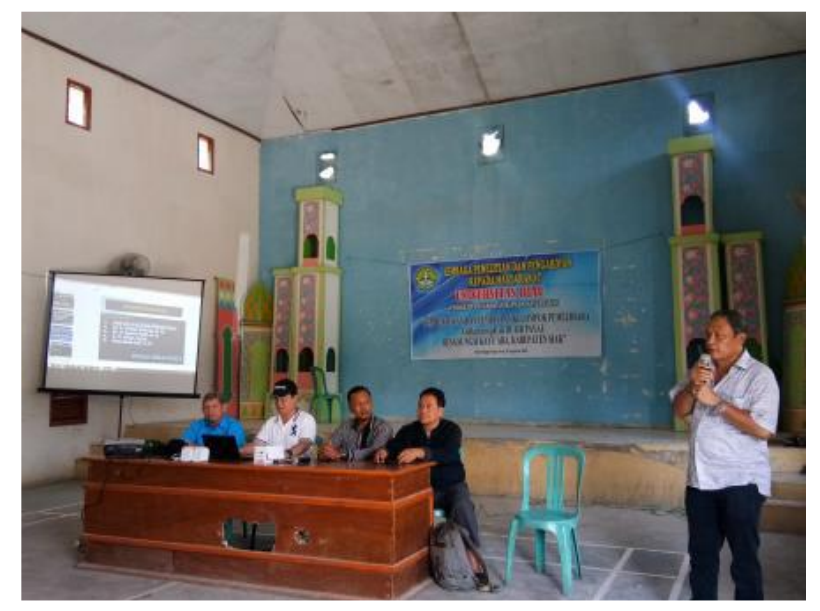

Gambar 3. Salah seorang anggota pim menyampaikan materi tehnik fermentasi budidaya $A$. microphylla. 


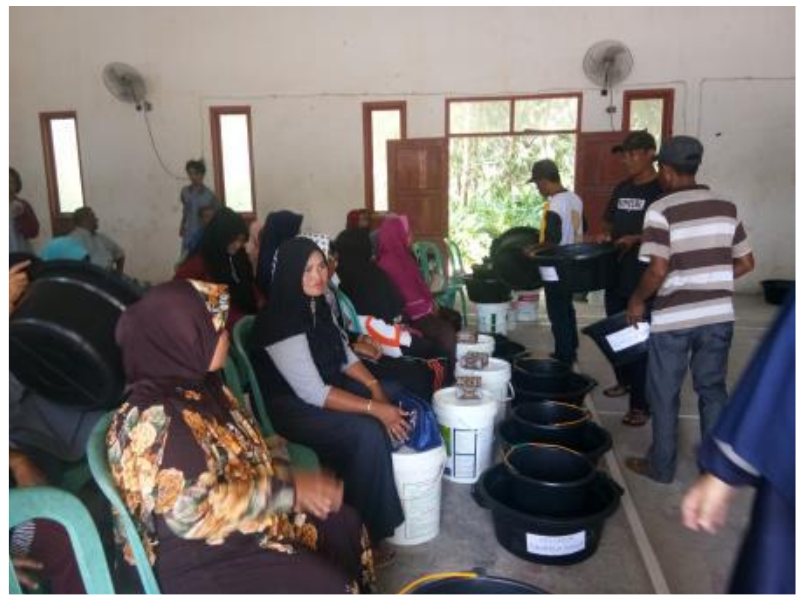

Gambar 4. Pembagian fasilitas wadah fermentasi dan wadah serta bahan pemeliharaan $A$. microphylla.

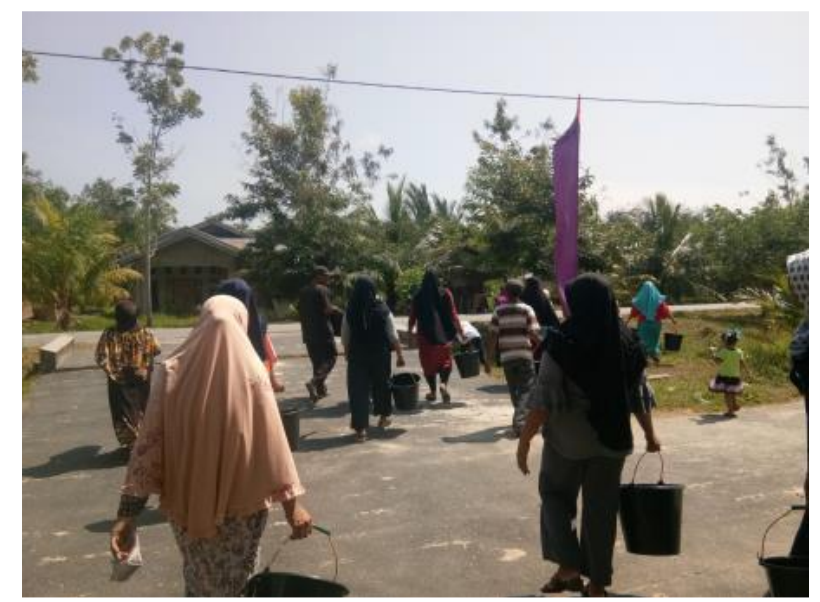

Gambar 5. Para peserta mengambil air sebagai bahan utama pemeliharaan A. microphylla.

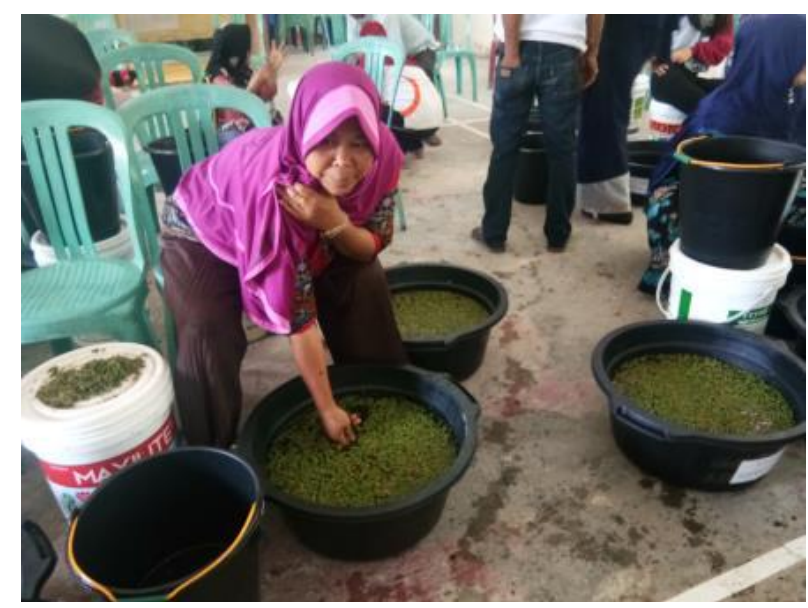

Gambar 6. Persiapan bibit A. microphylla dan pembagian kepada masing-masing anggota kelompok. 


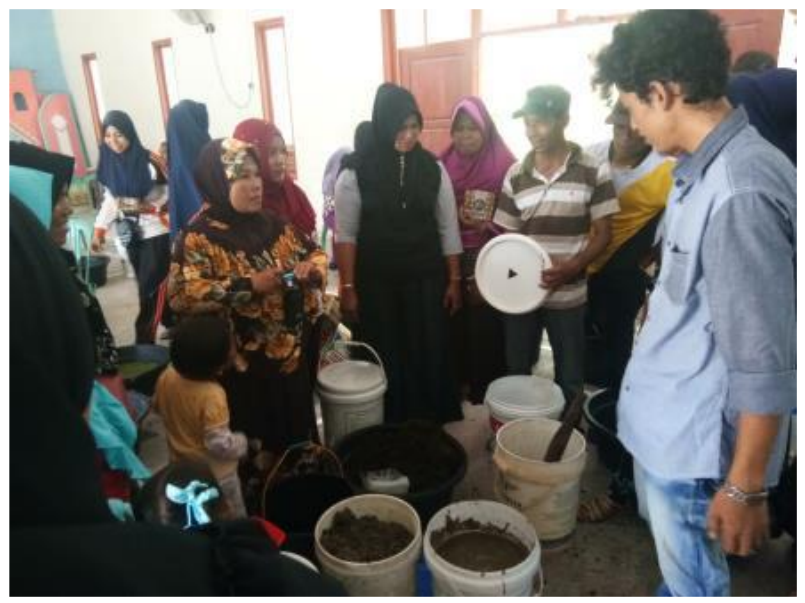

Gambar 7. Persiapan dan pelaksanaan fermentasi media tumbuh A. microphylla oleh masingmasing anggota kelompok.

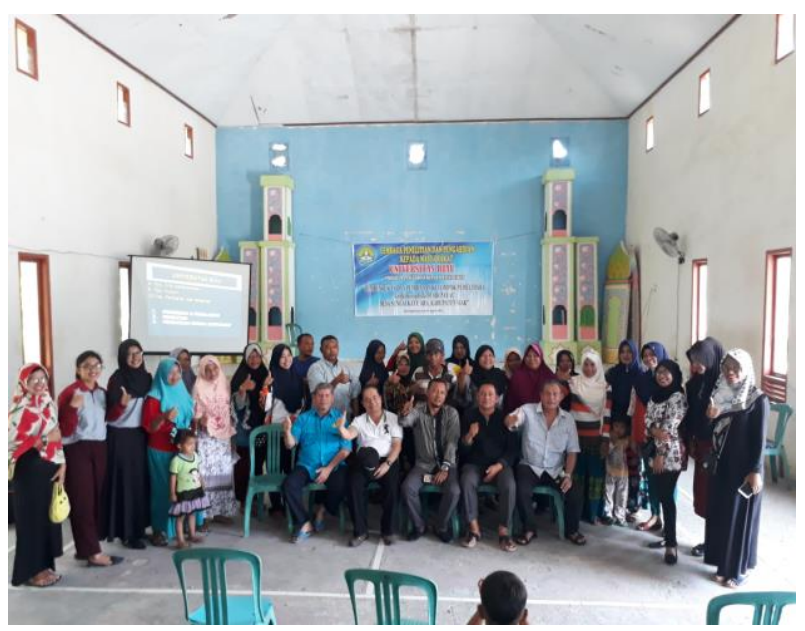

Gambar 8. Kelompok SUKARELA pembudidaya A. microphylla Desa Sungai Kayu Ara, 1 Kecamatan Sungai Apit, Kabupaten Siak.
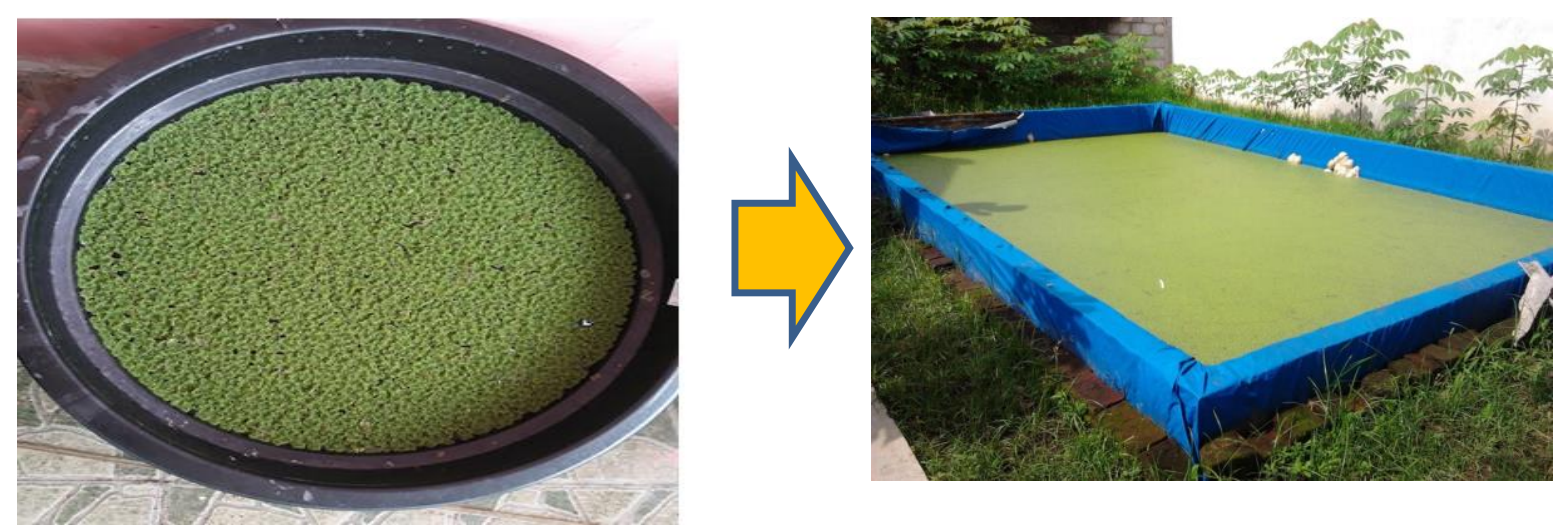

Gambar 9. Pemeliharaan Azolla dari skala ujicoba ke skala usaha.

Hasil ujicoba pada tingkat petani menunjukkan bahwa A. microphylla hanya dapat tumbuh normal pada air payau dengan salinitas rendah. Hasil ini bersesuaian dengan Effendi (2017) yang mencatat pertambahan individu biomasa A. microphylla pada air payau dengan salinitas di bawah 5 
ppt. Sesungguhnya makrofit A. microphylla ini adalah biota air payau. Makrofilik Azolla microphylla merupakan tumbuhan paku air (Maftuchah dan Winaya,. 2000) dengan ukuran yang relatif kecil (Christenhusz, 2014), memiliki panjang 1,5-2,5 cm. Beberapa genus dapat tumbuh di perairan payau, namun biota ini lebih disebut sebagai tumbuhan air tawar. Tumbuhan ini tumbuh di daerah tropis dan subtropis (Tjitrosoepomo,2014).

Pengukuran bobot mutlak biomasa menunjukkan hasil serupa, makrofit ini hanya dapat tumbuh normal pada salinitas 0 . Pada perlakuan salinitas $5 \%$ o, bobot biomasa biota ini hanya sampai pada hari ke 9. Demikian pula pada perlakuan salinitas $10 \%$, dimana makrofit ini dapat hidup dan tumbuh dan bercabang sampai hari ke 7 (Effendi, 2017). Fakta ini memperkuat data pertumbuhan biomas. Keadaan dapat dipahami mengingat makrofit ini adalah penghuni sejati air tawar. Azolla juga sangat mudah dibudidayakan dan sangat ideal sebagai pupuk hayati (biofertilizer) atau pupuk hijau untuk padi sawah. Azolla sudah berabad-abad digunakan di Cina, Vietnam dan Filipina sebagai sumber $\mathrm{N}$ bagi padi sawah (Chapman, 2010).

Aspek teknis pelaksanaan kegiatan pembentukan dan pembinaan kelompok masyarakat pemelihara A. microphylla di Desa Sungai Kayu Ara, Kecamatan Sungai Apit, Kabupaten Siak, juga dievaluasi dan diperoleh beberapa catatan berikut:

1. Kehadiran peserta dalam mengikuti kegiatan penyuluhan mencapai $99 \%$ dari jumlah yang diharapkan. Hal ini menunjukan bahwa para peserta penyuluhan sangat tertarik dan berminat terhadap materi yang disampaikan pada saat kegiatan penyuluhan.

2. Hasil pengamatan menunjukan bahwa adanya antusias dan keseriusan dari peserta selama pelaksanaan penyampaian materi penyuluhan. Selain itu tercatat pula bahawa para peserta tidak enggan mengajukan pertanyaan kepada para narasumber dan ikut aktif berdiskusi dalam kegiatan.

3. Peserta sangat aktif selama kegiatan diskusi berlangsung, dimana peserta menunjukkan semangat dan antuasias yang baik pada saat diskusi mengenai materi yang diberikan terkait budidaya azolla.

4. Sebelum kegiatan para peserta diajukan beberapa pertanyaan terkait mengenai budidaya azolla. Dari hasil diskusi menunjukkan bahwa sebagian para peserta mengatakan belum pernah mendengar tentang program tersebut dan belum mengetahui benar tentang manfaat dari budidaya azolla. Setelah kegiatan penyuluhan selesai dilaksanakan para peserta sudah mempunyai gambaran yang jelas tentang usaha mengelola dan budidaya azolla. Para peserta berjanji akan berusaha untuk memulai budidaya azolla dan mendukung penuh terkait program tersebut.

5. Berdasarkan hasil evaluasi yang dilakukan, peserta penyuluh telah mempunyai pengetahuan dan pemahaman yang cukup memuaskan untuk melakukan kegiatan secara mandiri atau berkelompok di masa yang datang di rumah mereka masing-masing.

\section{KESIMPULAN}

Dari hasil pengabdian masyarakat Pembentukan dan Pembinaan Kelompok Pemelihara $A$. microphylla di Desa Sungai Kayu Ara, Kecamatan Sungai Apit, Kabupaten Siak, Provinsi Riau dapat ditarik kesimpulan sebagai berikut;

1. Kegiatan pembentukan dan pembinaan pemelihara A. microphylla dianggap berhasil dengan baik.

2. Indikator keberhasilan itu dilihat dari aspek; kehadiran peserta, antusias dan keseriusan mengikuti pelatihan; keaktifan merespon materi penyuluhan yang diberikan dan keberhasilan penumbahan A. microphylla untuk setiap eserta.

3. Keberhasilan pelaksanaan kegiatan dilihat pula dari adanya pengembangan wadah pemilihraan yang dibuat secara mandiri oleh beberapa peserta pelatihan.

\section{SARAN}

Dari hasil pengabdian masyarakat Pembentukan dan Pembinaan Kelompok Pemelihara A. microphylla di Desa Sungai Kayu Ara, Kecamatan Sungai Apit, Kabupaten Siak, Provinsi Riau dapat disarankan hal-hal sebagai berikut; 
DINAMISIA - Jurnal Pengabdian Kepada Masyarakat Vol. 2, No. 2 Desember 2018, Hal. 184-192

1. Pembinaan para pemelihara akan lebih efektif bila dilaksanakan dalam bentuk kelompok.

2. Para peserta kelompok pemelihara relatif efek dilakukan oleh ibu-ib rumah tangga.

\section{UCAPAN TERIMA KASIH}

Penulis mengucapkan terima kasih kepada Lembaga Penelitian dan Pengabdian Kepada Masyarakat, Universitas Riau yang telah memberi dukungan peendanaan dan pelaksanaan kegiatan pengabdian kepada masyarakat ini.

\section{DAFTAR PUSTAKA}

[1] Chapman, A (2010). "Numbers of Living Species in Australia and the World. Report for the Australian Biological Resources Study. Canberra, Australia.

[2] Christenhusz, Maarten J.M. \& Chase, Mark W. (2014). "Trends and concepts in fern classification. Annals of Botany 113 (9): 571-594.

[3] Effendi, I. 2017. Pertumbuhan dan Kemampuan Fiksasi Nitrogen Makrofit Azolla microphylla dan Simbionnya di Ekosistem Air Payau. LPPM, Universitas Riau.

[4] Effendi, I., E. Saputra and Ellizal. 2017. Adaptation Of Azolla Mycrophyla To Brackish Water Ecosystem. Jurnal Ekologi, Habitat Manusia \& Perubahan Persekitaran di Alam Melayu (EHMAP), Universiti Kebangsaan Malaysia Edisi 2017.

[5] Gumilar, I. 2012. Partisipasi Masyarakat Pesisir Dalam Pengelolaan Ekosistem Hutan Mangrove di Kabupaten Indramayu. Jurnal Akuatik, Vol III. No. 2. September 2012.

[6] Kurniawan, A. W dan T. M. Prihtanti. 2018. Jenjang Partisipasi dan Determinan Partisipasi Petani dalam Introduksi Budidaya Padi Organik di Desa Pulutan, Kota Salatiga. Jurnal Peyuluhan. Vol 14, No 2 (2018)

[7] Kusumanto, D. 2014. Menghemat Pakan Pabrikan Sampai $22 \%$. Majalah Trubus Edisi Desember 2014.

[8] Madigan, MT; Martinko, JM, Dunlap PV, and Clark DP. 2009. Brock Biology of Microorganisms Twelfth Edition. pp. 403-404.

[9] Maftuchah dan Winaya, A. 2000. Komposisi Media Tumbuh Untuk Asosiasi AzollaAnabaena azollae. Vol.7, No.1, Hal 1-5. Pusat Bioteknologi Pertanian, Universitas Muhammadiyah Malang.

[10] Priyanto, D. 2016. Strategi pengembalian wilayah nusa tenggara timur sebagai sumber ternak sapi potong. Jurnal Penelitian dan Pengembangan Pertanian. Badan Litbang Pertanian. Kementrian Pertanian RI. Vol 35, No 4

[11] Purnama, RR. 2015. Ini Masalah Utama Kemiskinan Masyarakat Pesisir. Surat Kabar Harian Sindo. Sindonews.com. Rabu, 17 Juni 2015.

[12] Satria, A. 2015. Pengantar Sosiologi Masyarakat Pesisir. Cetakan 1, Edisi 2. Yayasan Obor Indonesia. Jakarta.

[13] Smith AR, Pryer KM, Schuettpelz E, Korall P, Schneider H, Wolf PG. 2016. A classification for extant fern. Taxon 55:705-731.

[14] Sudjana, B. 2014. Pengunaan Azolla Untuk Pertanian Berkelanjutan. Jurnal Ilmiah Solusi Vol. 1 No. 2 April-Juni 2014: 72-81

[15] Tjitrosoepomo G. 2014. Taksonomi Tumbuhan: Schizophyta, Thallophyta, Bryophyta, Pteridophyta). Gadjah Mada University Press. Cetakan ke-10. 309 halaman. 